\title{
West Germans are taking most top jobs at eastem institutes
}

Berlin and Munich. An attempt to 'seed' new research institutes in eastern Germany with western scientists is occurring only at the top, according to a Nature survey of 97 institutions.

In 1991, following the closure of all institutes of the Academy of Sciences in the former East Germany, Germany's science council, the Wissenschaftsrat, recommended that their successors should be populated by a mixture of eastern and western scientists. A figure of about 10 per cent westerners working at all levels - was considered to be an ideal target to speed up cultural integration.

But that has not happened. Although statistics are not collected, the government acknowledges its failure to achieve such a balance, the result being too many westerners at the top and almost none at the bottom.

With a substandard research infrastructure and problems such as chronic shortage of housing and poor schooling, the eastern Länder are not very attractive to postdoctoral researchers used to better standards. But the chance for promotion changes the equation. The opportunity to head a new institute or department has proved to be a powerful magnet for those facing obstacles to career advancement in the west.

According to the Nature survey, the open competition in the new Länder has resulted in the selection - generally by western scientists - of a majority of their colleagues to top positions in institutes of basic research. Only one of nine heads of the new national research centres is an east German, and roughly half the department heads and three-quarters of group leaders hail from the west.

Similarly, only one of the three heads so far recruited for the newly founded Max Planck institutes are east Germans. Although staffing of the new institutes is not complete, department heads follow the same pattern; by contrast, the vast majority of group leaders appointed so far are from the east.

So-called 'blue list' institutes - independent research establishments with equal funding from the federal and Länder governments - have proven to be a little more receptive to east Germans. Although also very much in flux, one third of the institute heads so far recruited, and around 80 per cent of the department heads and group leaders, are east Germans.

The applied research (Fraunhofer) institutes, by contrast, have recruited predominantly from the east, a reflection of the relative strength of product-orientated research in the former DDR German Democratic Republic and possibly also the fact that researchers in this area were less likely to be politically compromised.

Martin Holzhauer, a biochemist from

Who gets the top jobs in the East?

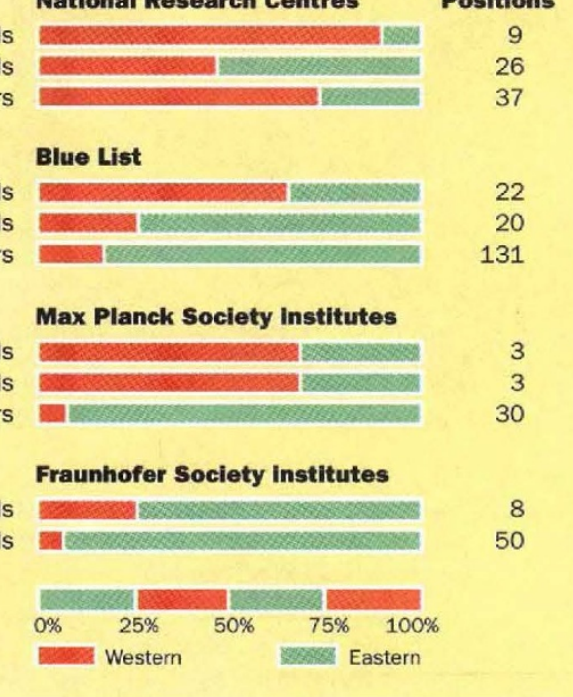

East Berlin, says that the figures are disappointing, particularly when so many research groups were given such positive reviews by the Wissenschaftsrat and so many genuinely good east Germans have been overlooked. Detlev Ganten, head of the Max Delbrück Centre in Berlin-Buch, agrees. "The depressing part for east Germans is that the top positions are being taken up by west German scientists - this must be considered against a background of 100 per cent east Germans at the outset. It is an important psychological point in the whole process of reunification."

One of the eight national research centre heads in the new Länder who hailed originally from the west, Ganten believes that local scientists will fare better over the next few years. Although the overall ratio of westerners to easterners in his centre is less than one in ten, Ganten hopes to appoint more group leaders and department heads from within to strike a better balance at the upper levels.

Alison Abbott \& Cornelia Koob
CHINA IN BRIEF

Beijing. The Chinese government has granted 100 research institutions the right to make their own deals on foreign trade in a move intended to increase exports of high-technology products. High-technology products comprise less than 5 per cent of the total, and the government has given institutes operated by 28 ministries the freedom to promote their own technologies in the hope of doubling that figure. Such exports have grown by an average of 32 per cent a year since 1986 , led by 3,000 high-technology companies operating in 52 national high-technology development zones.

Determined not to be left behind, a hundred Chinese universities have joined to form a high-technology group corporation that will occupy a high-rise office building under construction in Shanghai as well as five factories to manufacture products developed in university laboratories. The State Education Commission encouraged the creation of the corporation to hasten the transfer of new technology from campus to market. Chinese universities have had mixed success in forming individual companies based on academic research, with Beijing and Qinghua universities leading the way, and there remains concern that the quality of undergraduate education will suffer if too much attention is given to applied work.

The government has proposed a restructuring of ministries to reduce employment by 20 per cent and to hasten the development of new technology. The ministry of aviation and aerospace industry, for example, will be converted into two specialized corporations, one for aviation and one for aerospace, to encourage the rapidly growing aerospace industry. At the same time, the ministry of machinery and electronic industry will become separate ministries to reduce the administrative burdens on the burgeoning electronics industry.

China's desire to cooperate with the rest of the world to stimulate economic development must remain secondary to the country's need to defend itself, warned the government's minister of national security in a recent televised address explaining the duties of each citizen under a law passed in February. The minister, Jia Chun-Wang, said that "a very small number of foreign hostile forces have never given up hope of penetrating into China and are doing everything they can to overthrow the Chinese government", and science and technology are viewed as major targets. The budget and details of a high-technology programme begun in 1986, for example (see Nature $359,177 ; 1992)$, are regarded as state secrets and remain classified, along with most of the meteorological, topographical and surveying data collected by government scientists.

You Qui Li 